\title{
Awareness of Library 2.0 Applications among Library and Information Science Professionals at Annamalai University, India
}

\author{
S. Thanuskodi
}

Department of Library \& Information Science, Alagappa University, 630 003, Karaikudi

\begin{abstract}
With the widespread embracement of Web 2.0 technologies, pervasiveness of handheld devices, and the advent of Library 2.0, libraries have to grapple and manage the changing use patterns and expectations of its varied clientele. How do librarians, new and old be trained and be prepared for the new age libraries, where the demarcations between the physical and digital library spaces and services are not as clear as before, where library customers demand for services that they can get using their handheld gadgets round the clock, from anywhere in the world, and where the roles of librarians and libraries, customers of libraries, internet and internet content producers and service providers are becoming less clear than ever before? The paper has investigated the level of awareness of Library 2.0 applications among library and Information science professionals at Annamalai University, India. The paper also identified perceived factors and problems that could influence successful implementation of Library 2.0. The findings showed that there was moderate awareness among the LIS professionals with Library 2.0 applications. The findings also indicated that there was high level of computer expertise among the respondents in terms of web browsers and search engines, in addition to high level of utilization in some of the Web 2.0 applications. In addition, the study observed high rates of using blogs and Wikipedia among the librarians.
\end{abstract}

Keywo rds Web 2.0, Library 2.0, University Libraries, Facebook, Flicker, Youtube, Wikis and Social Networking Sites

\section{Introduction}

The most common definition of Web 2.0 is that of Tim O'Reilly. In his article O'Reilly (2005) explained that companies that survived the collapse of the technological sector during the 1990s had in common particular methods, concepts and technologies that allowed them to be cutting-edge compared to their competitors[1]. These companies offered assessments of their products and services online, and customers used them to write personal comments and suggestions, thus creating a network of information that was then used by the same company to improve their products and services. The request for new methods of communication online capable of satisfy ing the various needs of users have facilitated the development of Web 2.0 technologies like the folksonomie, keywords that are created by those who organizes the information available online; the AJAX, that allow an interactive and dynamic use of Web applications; and feeds that make interoperable content of different applications or platforms. Su mmarizing, Web 2.0 is an assortment of technologies that offer a distinct level of

* Corresponding author:

thanuskodi_s@yahoo.com (S. Thanuskodi)

Published online at http://journal.sapub.org/library

Copyright (C) 2012 Scientific \& Academic Publishing. All Rights Reserved interaction with the user. The concept of allowing people to exchange information freely online is part of the dynamic of the Internet. This does not means that paper information should or will be eliminated, because the two sources of information are used for different purposes. How did we move from Web 2.0 to the Library 2.0? The two terms have created confusion because it was not clear what they were. It was thought that Library 2.0, like Web 2.0, was a new type of technology, while it referred to the applications of Web 2.0 tools within the library field (Crawford, 2006)[2]. Library 2.0 can be defined as a set of innovative technologies and services that are integrate with the library, facilitating the use of library resources and services, allowing library user to participate and keeping the librarians updated in their field (Casey, 2006). It is my conviction that it is the technology that must adapt to our way of life and not vice versa[3].

\section{WEB 2.0}

Libraries are increasingly enhancing their website by introducing Web 2.0 features. One such library that undertook a major project to re-shape its website and incorporating blogs and Wikis can be found in the University of Houston. The incorporation of these features has allowed the website to be more flexible and adaptable. With the adoption of these tools, staff is better able to update the 
content of the website instead of just relying on the website master. Casey (2007) envisioned that the next version of the Library catalogue or OPAC will have to include many of the attributes that comprise the definition of Web 2.0. Key requirements include user participation, customization, maximum usability, and greatly enhanced discovery[4]. For example, the Hennepin County Public library has improved their catalogue by giving their customers the ability to write reviews on items in the catalogue. North Carolina State University Libraries has used faceted metadata search to interact with their ILM system. This provides users the search results. Several libraries have used the Wiki tool in the provision of services. At the National Library of Singapore (NLS), a wiki-like platform created for the librarians to work collaboratively and concurrently on providing answers to the users' enquiries. This allows any staff to tap on the collective wisdom of the communities of subject librarians and provide quality answers to their queries.

Besides using Wiki as a collaboration tool, some libraries have used it to create research guides, for examp le, the Oh io University created a Biz Wiki to assist business researchers with their research. The Biz Wiki contains a variety of content, including information about reference books, websites, research guides, how-to documents and more. An advantage of using the wiki to create the research guide is the ability to add and edit content easily and anywhere to keep it updated. The wiki also allows the librarian to determine which content are used most and this can influence the type of content to focus on. The use of messaging such as twitter and SMS text messaging has enhance library services via hand phones. The latter have also been incorporated into enquiry and reference services. Cellular phone usage (including SMS usage) is very high in Singapore. Singapore's cellular phone penetration rate for May 2007 stood at $109.1 \%$. Trends such as these suggest that SMS is an ideal way to reach out to a greater pool of potential users of our reference enquiry service. Adding the advantages of portability of the cellular phone and ease in using SMS, it becomes clear that SMS provides an alternative and potentially ideal mode of posting reference enquiries for users on the move, or who may not have the luxury of visiting the library due to their schedules. Against this backdrop, NLS launched the SMS Reference Serv ice on 11 April 2006 as an additional convenient channel for users to pose questions. NLS has innovatively overcome the text limitation of 160 characters by delivering answers to complex enquiries through a URL link sent to the user's cellu lar phone. Upon opening up the URL link either through the cellular phone directly, or through a computer or PDA, the user would be able to view the full reply easily. This includes links to e-resources that are recommended to users asking the questions (Foo, $\mathrm{Ng} \& \mathrm{Soh}, 2008$ )[5]. Libraries have also used Web 2.0 p latform as a channel for collection development. For examp le, the National Library of Australia has used Flickr to expand their collection of pictures on Australia. Social networking website provides great opportunities for Librarians to interact with their users as it places them in the dig ital social space of their users.

The websites can be use effectively for outreach and promotion. Librarians can get first hand information about the users through interacting with them. They can then understand the behaviour of the users and design services to meet the needs of these users. Two libraries that have successfully used these social networking websites are the Hennepin County Library (HCPL) and the Public Library of Charlotte \& Mecklenburg County (PLCMC). HCPL has embedded a search box in their MySpace profile to enable the users to access their collection while PLCMC features blog post as well as an embedded IM window. Libraries are also tapping into social video such as video blogging and YouTube to create a presence at these sites. These are being used as marketing tools. One library that makes use of video blogging is the Arlington Heights Memorial Library. Videos of programmes and "What's new" segments and interviews were posted at the site. Podcast is now popularly used by libraries for book talk. Another prevalent use of podcast is for storytelling. For example, the Denver Public library offers podcasts of share nursery rhymes, fairy tales and children stories as recorded by the librarians.

Some libraries have also used podcast to provide library instructions and information literacy programmes. We have list some example of Web2.0 application in libraries, Libraries will have to decide on the application of Web2.0 technologies that best suits their environment and their customers. In order to embrace this technology, a logical first step would be for the library staff to learn more about the various Web2.0 technologies and best practices in libraries. There are already ready learning Web 2.0 courses available on the web. For example, the PLCMC has sponsored such a learning course and any library can adapt this free program for its use. Subsequently, new ideas to incorporating Web 2.0 technologies to provide new functions and services can emerge, evaluated and decided. Before embarking on adopting the technologies on a large scale, it is good practice and prudent to develop a prototype and build a proof of concept to test viability of the new function or service prior to a pilot and subsequent full implementation. Library schools have an equally important role to play in this new environment. They can also help to equip new generations of librarians with competencies and skills to adopting and use Web 2.0 technologies through curriculum development and other initiatives.

\section{WEB 2.0 + LIBRARY = LIBRARY 2.0}

Libraries were once the guardians of knowledge, and the point at which those seeking existing knowledge would engage with it. With the rise of Google, A mazon, Wikipedia and more, there is an oft-stated fear that many users, much of the time, will bypass processes and institutions that they perceive to be slow, unresponsive, unappealing and 
irrelevant in favor of a more direct approach to services offered by others that just might be 'good enough' for what they need to do. Libraries should be seizing every opportunity to challenge these perceptions, and to push their genuinely valuable content, services and expertise out to places where people might stand to benefit fro $m$ them; p laces where a user would rarely consider drawing upon a library for support. Web 2.0's principles and technology offers libraries many opportunities to serve their patrons better, and to reach out beyond the walls and $\mathrm{Web}$ sites of the institution to reach potential beneficiaries where they happen to be, and in association with the task that they happen to be undertaking. With these approaches, we take our existing wealth of data, and make it work much harder. We begin to break down the internal silos of the separate systems within a single library, and connect those components to one another, and to related components and services far beyond the building. At a technical level, we make it possible for searchers to be presented with choices to view online, borrow locally, request from afar, buy or sell as appropriate to their needs and circumstance. The beauty of Web 2.0 and Library 2.0 is the level of integration and interoperability that is designed into the interface through the library portal or intranet. That's where the real power to enhance the user experience is. In order to take advantage of the concepts inherent in Library 2.0, all the advanced functionality and features of web 2.0 should be integrated into the content.

\section{Review of Literature}

Web 2.0 tools allow users to create, describe, post, search, and communicate online content in various forms - which range from music, bookmarks to photographs and documents. (Macasskill and Owen,2006) The literature also reveals that Web 2.0 tools have an all pervasive impact through out the society[6]. Huffman, K.(2006), stresses that web 2.0 is more of a social movement. Web 2.0 is not any advancement in technology[7]. Miller(2005)opines that the people are hyping the Web2.0[8] and Notess (2006) asserts that web 2.0 indicates a second wave of web techniques which makes information sharing, dissemination and collaboration among the users more interactive[9]. Davis has referred to web 2.0 as an attitude not a technology. Franklin and Van Harmelen,2007 have called it a technology change[10]. Clyde,L.A.(2004) call it a social revolution[11]. Virkus (2008) states that these tools and services facilitate new myriad opportunities of connectivity, communication and collaboration and sharing of information[12]. The Library staff should encourage and promote and educate the teachers about the power and pedagogical opportunities offered by web2.0 (Cohen,2008)[13]. The web2.0 in general and blogs in particular can be used for marketing library services (Draper, Lani and Turn age) Chu and Meulemans (2008) report that online social networking sites are very popular among the students[14]. They highlight that Myspace, Facebook-two widely adopted social networking sites can be used in university libraries for imparting library instruction, reference and outreach.

The literature survey shows that most of the experts have highlighted the web 2.0 and s applications. Many of the experts have asserted that it is more of a social phenomenon than a major stride in technology. The application of $\mathrm{Web} 2.0$ in libraries and information centres is popularly known as Library 2.0. Web 2.0 is proving to be engines of change for academic libraries. These tools help library professionals organize their materials, enhance services towards the users and internal functions. The application of these tools also increases demand for services in virtual environment (Kajewski,2007)[15]. Bradley (2007) states that the libraries should explore novel ways through the use of web 2.0 of communicating and attracting the users. Miller has keenly advocated the use of web2.0 by libraries. These can be used for serving the users in a better manner and attracting the potential users towards the Library. Miller further cautions that if the libraries don't use the tools to enhance the services, they are likely to be ignored by the users. The web 2.0 tools which can enhance library services are wikis, blogs, RSS[16].

\section{Objectives}

The objectives of the study were:

- To study librarians' awareness of Library 2.0 applications.

- To study librarians' perceptions of Library 2.0 applications.

- To identify factors that will influence the successful implementation of Library 2.0 applications in libraries.

\section{Methodology}

The present study was carried out to assess the awareness of web 2.0 concept among library and information science professionals of the Annamalai University. Research method followed was a survey method. Questionnaire tool was used to collect the data. The sample consists of 60 library and information science professionals in the Annamalai University.

Table 1. Responses by Gender

\begin{tabular}{|c|c|c|}
\hline Gender & Number & Percentage \\
\hline Male & 42 & 70.00 \\
\hline Female & 18 & 30.00 \\
\hline Total & 60 & 100.00 \\
\hline
\end{tabular}




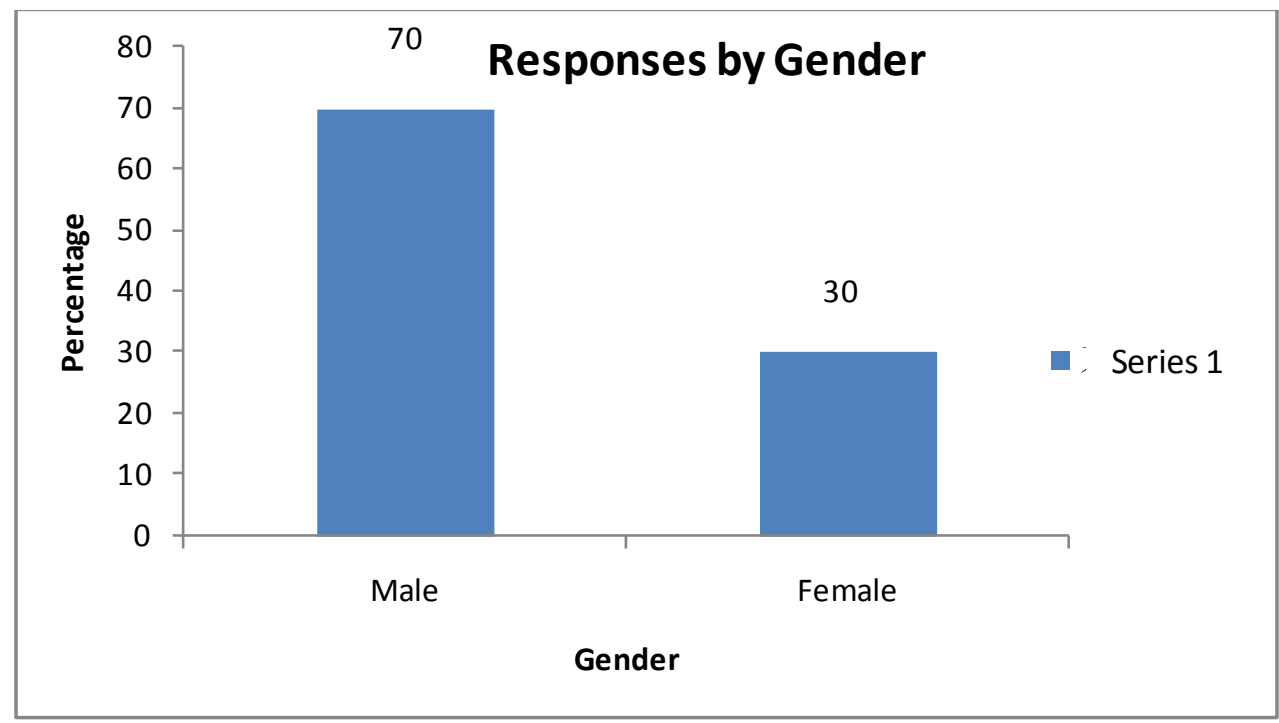

Figure 1. Gender wise Respondent

\section{Analysis of Data}

Analys is of data is the ultimate step in research process. It is the link between raw data and significant results leading to conclusions. This process of analys is has to be result oriented.

Table-1 describes $42(70 \%)$ of respondents were male, while $18(30 \%)$ were female[Fig. 1$]$.

\subsection{Computer Expertise}

Respondents were asked to indicate their perceived level of computer expertise. The questions included expertise in Microsoft applications, web-browsers and also search engines.

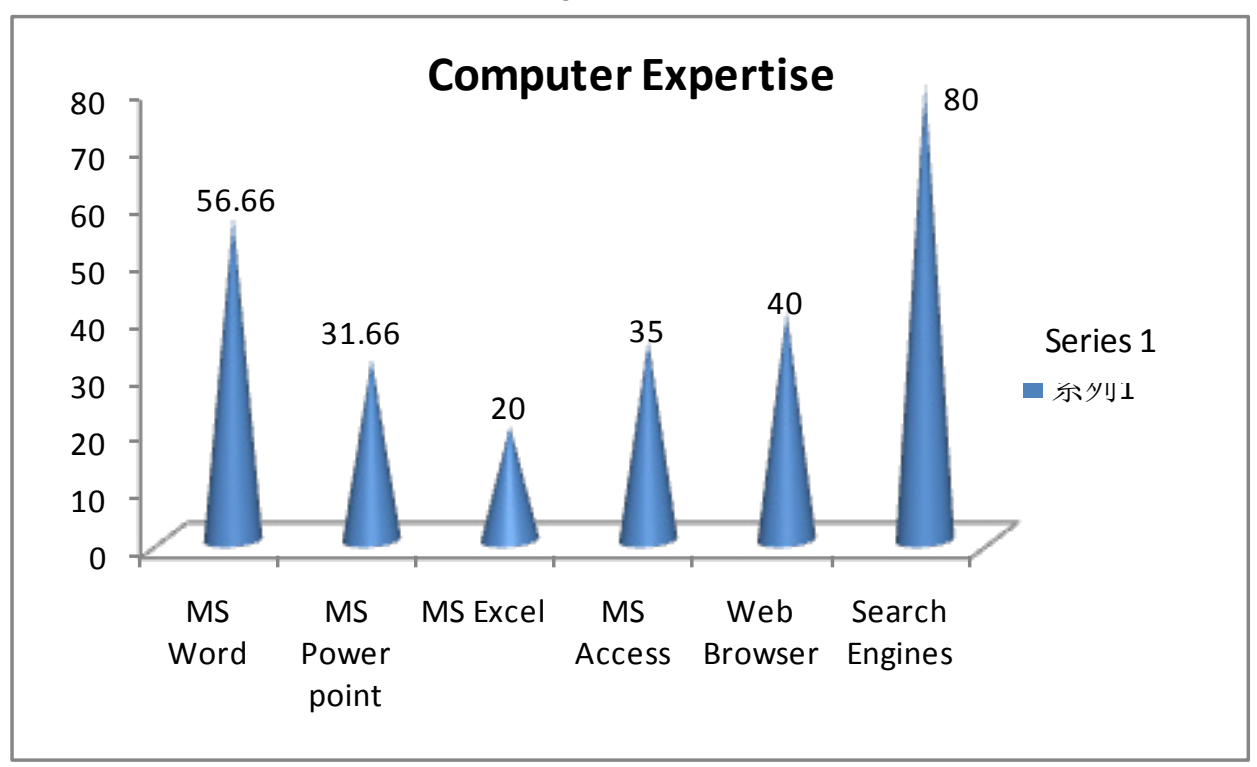

Figure 2. Computer Expertise

Table 2. Computer Expertise

\begin{tabular}{|c|c|c|}
\hline Computer Expertise & Number & Percentage \\
\hline MS Word & 34 & 56.66 \\
\hline MS Power point & 19 & 31.66 \\
\hline MS Excel & 12 & 20.00 \\
\hline MS Access & 21 & 35.00 \\
\hline Web Browser & 24 & 40.00 \\
\hline Search Engines & 48 & 80.00 \\
\hline
\end{tabular}


From Table 2 above, it was found that, 34(56.66\%) respondents using MS word, while only 19(31.66\%) using MS Power Point. With regard to expertise in MS Excel, $12(20 \%)$. Majority of the respondents $24(40 \%)$ regarding to web browser expert ise. The findings further revealed that 48 $(80 \%)$ themselves as having a very high expert ise in using search engines. Information on the above indicates the library professionals expertise on basic application tools in libraries, which could also indicate readiness in adopting Web 2.0 tools.

\subsection{Internet Use}

Table-3 highlights the location from where the Internet and electronic resources are mostly accessed by the respondents. A majority of the respondents i.e.63.34\% access the Internet from the library followed by $20 \%$ access from home, $13.33 \%$ access from college and university office and remaining $3.33 \%$ of the respondents access from Internet café[Fig. 3].

Table 3. Preferred place to access to Internet

\begin{tabular}{|c|c|c|}
\hline Location & Number & Percentage \\
\hline Library & 38 & 63.34 \\
\hline $\begin{array}{c}\text { College / } \\
\text { University office }\end{array}$ & 8 & 13.33 \\
\hline Café & 2 & 3.33 \\
\hline Home & 12 & 20.00 \\
\hline Total & 60 & 100.00 \\
\hline
\end{tabular}

Table 4. Int ernet Use Frequency

\begin{tabular}{|c|c|c|}
\hline Duration & Number & Percentage \\
\hline Daily & 29 & 48.33 \\
\hline Weekly twice & 18 & 30.00 \\
\hline Weekly & 13 & 21.67 \\
\hline Total & 60 & 100.00 \\
\hline
\end{tabular}

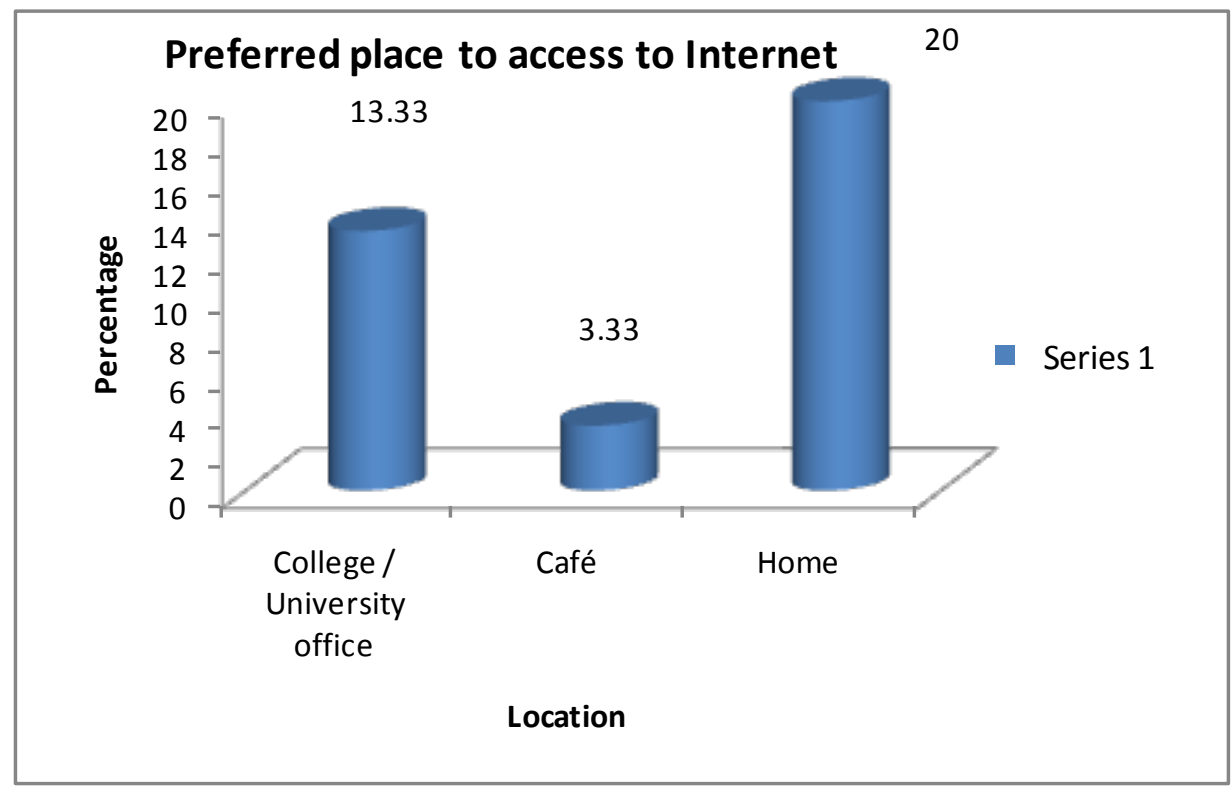

Figure 3. Internet Use

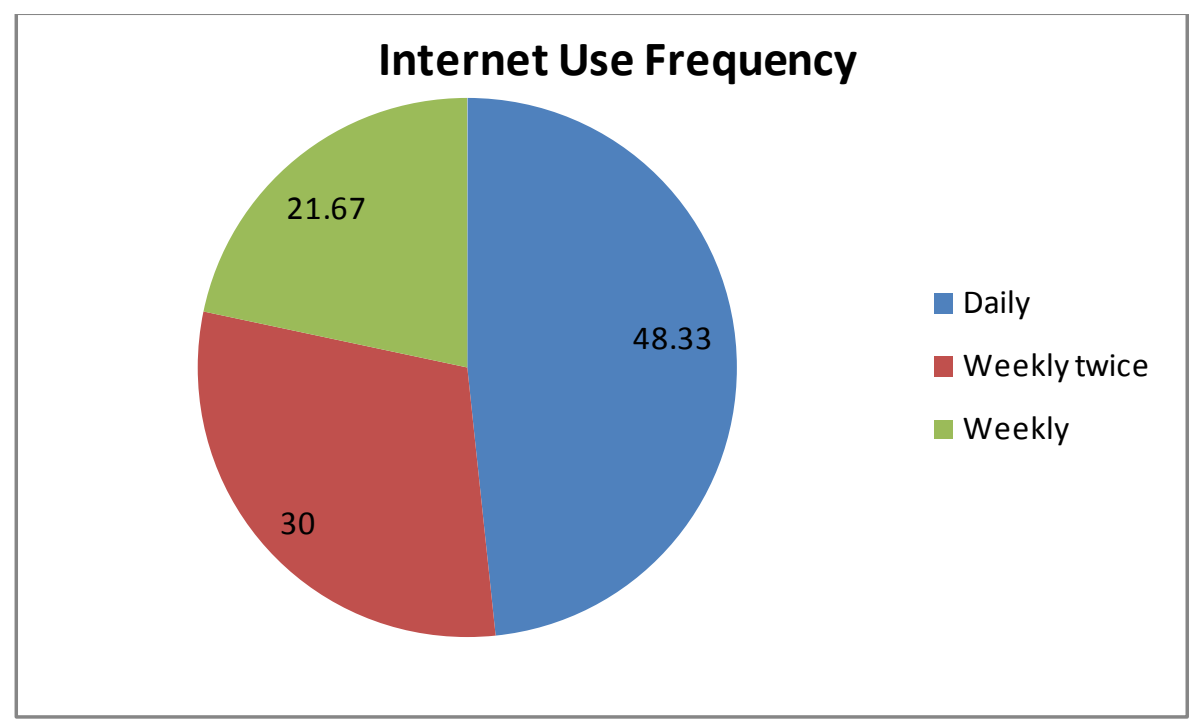

Figure 4. Frequency of Internet Use 
In response to the question how frequently do you use Internet? The respondents have responded in different ways (Table-4) Majority of respondents used Internet daily $(48.33 \%)$, weekly twice $(30 \%)$. Only few respondents (21.67\%) used internet weekly[Fig.4].

Table 5. Purpose for using Internet

\begin{tabular}{|c|c|c|}
\hline Purpose & Number & Percentage \\
\hline Acquiring information & 48 & 80.00 \\
\hline Study & 32 & 53.33 \\
\hline Entertainment & 15 & 13.33 \\
\hline Contact with Others & 25 & 41.66 \\
\hline Online community & 21 & 35.00 \\
\hline Online Shopping & 10 & 16.66 \\
\hline e-Banking & 12 & 20.00 \\
\hline Free Resources & 28 & 46.66 \\
\hline Others & 18 & 30.00 \\
\hline
\end{tabular}

Note: Total sample exceeds the required size since the questions are multiple choices

The Library and information science professionals were asked question about the purpose for which they access Internet. A study of data in table-5, it is clear that most of the respondents $80 \%$ use internet for acquiring information. $53.33 \%$ of the respondents use internet for study, $46.66 \%$ respondents use for free resources and $41.66 \%$ of the respondents use internet for contact with others. A few respondents use internet for e-banking (20\%) and online shopping (16.66\%)[Fig.5].

\subsection{Awareness of Web 2.0}

The respondents were asked to indicate their awareness with regard to the following statements in Table 6. 28 $(46.66 \%)$ respondents were not aware of Web 2.0 applications being employed in libraries. The other $32(53.33 \%)$ respondents who indicated awareness of Library 2.0, admitted to the following: Out of 48 respondents only 5 $(8.34 \%)$ respondents have heard about Web 2.0 applications employed in library, but do not know how, 10(10.66\%) respondents have heard about Web 2.0 applications being emp loyed in library and have seen some of the applications, but do not use it, and 17(28.34\%) respondents have heard about Web 2.0 applications in library and have used some of its applications.

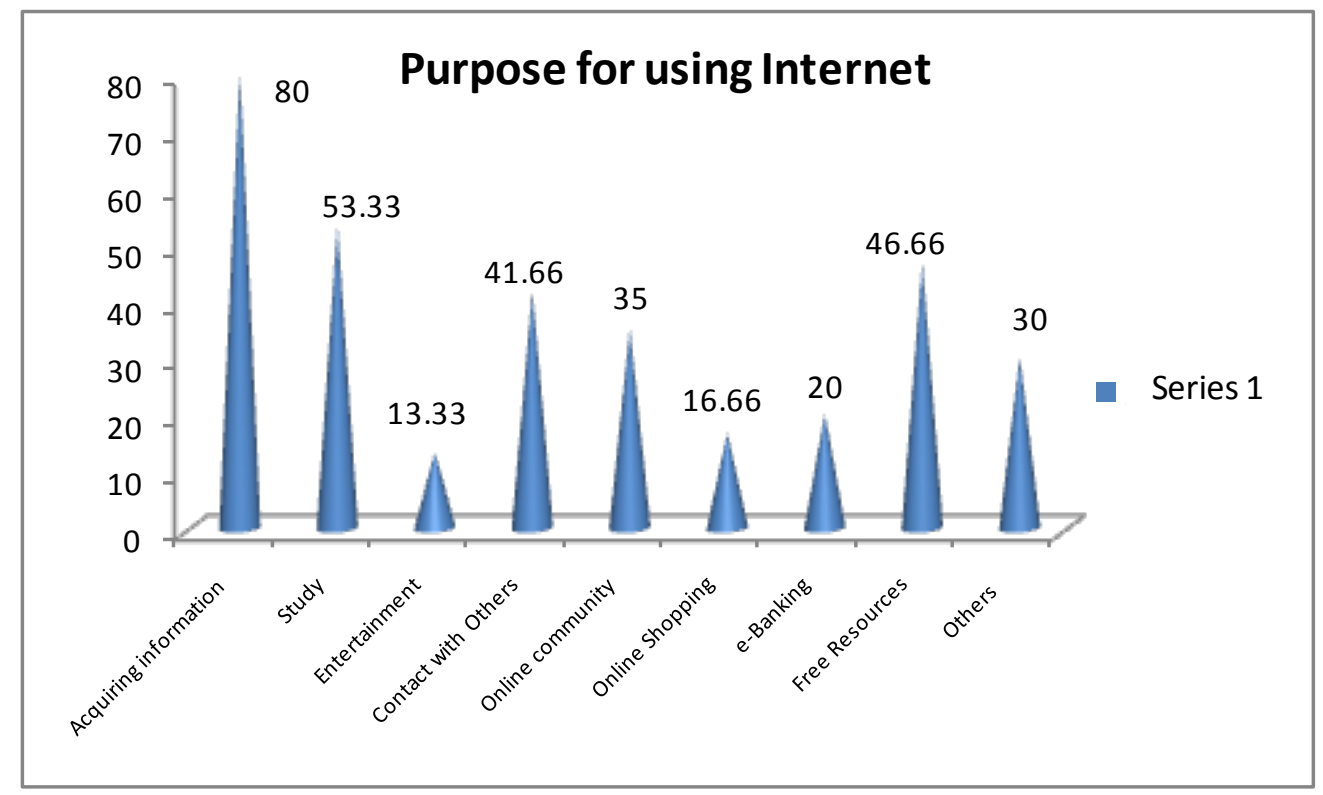

Figure 5. Purpose of using Internet

Table 6. Awareness of Web 2.0 Applications

\begin{tabular}{|c|c|c|}
\hline Statement & Number & Percentage \\
\hline Did not know that Web2.0 applications employed in library & 28 & 46.66 \\
\hline I have heard about Web2.0 applicat ions employed in library, but do not know how & 5 & 8.34 \\
\hline $\begin{array}{c}\text { I haveheard about Web2.0 applicat ions employed in library, and have seen some of } \\
\text { the applications, but do not use the applications }\end{array}$ & 10 & 10.66 \\
\hline $\begin{array}{c}\text { I have heard about Web2.0 applications employed in library, and use some of the } \\
\text { applications }\end{array}$ & 17 & 28.34 \\
\hline Total & 60 & 100.00 \\
\hline
\end{tabular}

\subsection{Use of Web 2.0}

Respondents were asked to indicate their level of utilization with regards to the Web 2.0 in general (Table 7). 
Table 7. Use of Web 2.0 Tools

\begin{tabular}{|c|c|c|}
\hline Web2.0 Tools & Number & Percentage \\
\hline Read blogs & 42 & 70.00 \\
\hline Add posts to blogs & 10 & 16.66 \\
\hline Read Wikipedia & 35 & 58.33 \\
\hline Add entries in Wikipedia & 19 & 31.66 \\
\hline Use RSS feeds & 6 & 10.00 \\
\hline Participate in social networking & 15 & 25.00 \\
\hline Use pictures in Flickr & 8 & 13.33 \\
\hline Add pictures in Flickr & 5 & 8.33 \\
\hline
\end{tabular}

Note: Total sample exceeds the required size since the questions are multiple choices

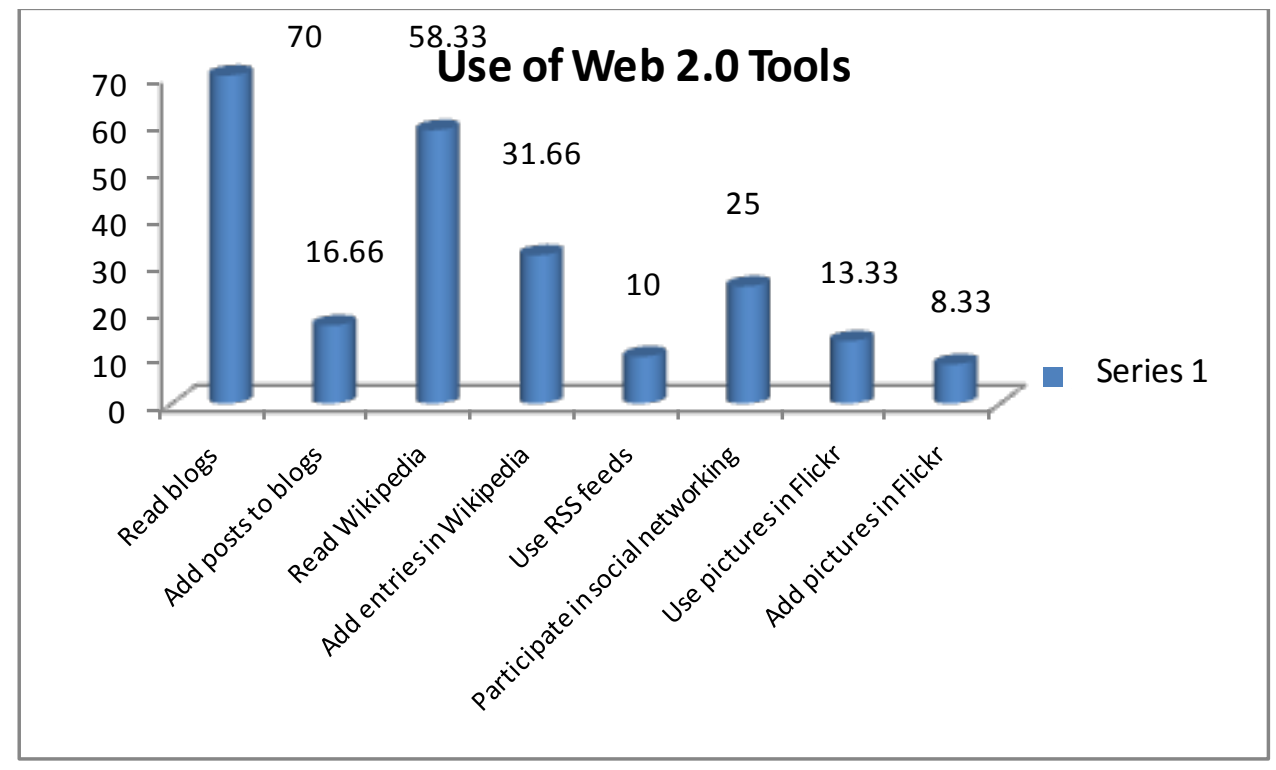

Figure 6. Usage of Web 2.0 Tools

Almost majority of the respondents, i.e. $42(70 \%)$ had read blogs. More than half of them $(58.33 \%)$ had added posts to blogs. The findings also showed that 90\% (27) of the respondents had read entries in Wikipedia, but only $19(31.66 \%)$ had added entries in Wikipedia. $6(10 \%)$ respondents had used RSS feeds and 15(25\%) had participated in social networking. $8(13.33 \%)$ respondents said that they had used pictures from Flickr and only 5 $(8.33 \%)$ of the respondent had added pictures to Flickr [Fig.6].

\subsection{Training Needs}

Table 8. Training Needs

\begin{tabular}{|c|c|c|}
\hline Training & Number & Percent age \\
\hline $\begin{array}{c}\text { Introduct ion to Web 2.0 technologies } \\
\text { and tools }\end{array}$ & 37 & 61.66 \\
\hline Workshops for using blogs & 20 & 33.33 \\
\hline Workshops for using wikis & 28 & 15.55 \\
\hline Workshops for using social net working & 19 & 31.66 \\
\hline Workshops for managing tags & 15 & 25.00 \\
\hline $\begin{array}{c}\text { Workshops for using instant messaging } \\
\text { (IM) }\end{array}$ & 8 & 13.33 \\
\hline
\end{tabular}

Note: Total sample exceeds the required size since the questions are multiple choices

Respondents were asked to indicate their training needs on the use of Library 2.0. Table 8 below shows that majority 37
$(61.66 \%)$ of the respondents indicated that training on introduction to Web 2.0 technologies and tools were important. The study found that, 20 (33.33\%) of the respondents rated that workshop for using blogs as important. When asked about workshop on using wikis, only a very few of the respondents (15.55\%). More than one fourth $(31.66 \%)$ of the respondents indicated workshops for social networking was important. The study also found that, 15 $(25 \%)$ of the respondents rated that workshop on managing tags as important. Finally, with respect to workshop on IM, 8 $(13.33 \%)$ respondents indicated such workshop as important. Thus, majority of the respondents had indicated trainings on the various applications of Web 2.0 in libraries as important.

\subsection{Factors Influencing Successful Imple mentation of Library 2.0}

Respondents were given an open-ended question that sought their opinion on factors that could contribute in successfully implementing Library 2.0. All responses were analyzed and grouped under common themes (Table 9). The highly cited factors were that of Training and Librarians' awareness, followed by management support and Internet Access. The remaining medium cited factors indicated Knowledge \& skills of staffs, Equipments \& infrastructures and Staffs commitment \& cooperation. Other factors listed 
very few like Willingness to change, Time availability, Proper planning, Good collaboration (library \& users), Response from users, Maintenance, Promotion/ marketing strategies and Budget.

Table 9. Fact ors Influencing the Implement ation of Web 2.0 Application

\begin{tabular}{|c|c|c|}
\hline Fact ors & Number & Percentage \\
\hline Management support & 45 & 75.00 \\
\hline $\begin{array}{c}\text { Knowledge \& skills of staffs } \\
\text { Equipments \& infrastructures (soft ware, } \\
\text { hardware etc) }\end{array}$ & 40 & 66.66 \\
\hline Training & 35 & 58.33 \\
\hline Willingness to change & 20 & 86.66 \\
\hline Budget & 8 & 33.33 \\
\hline Good collaborat ion (library \& users) & 19 & 33.33 \\
\hline Response from users & 15 & 25.66 \\
\hline Proper planning & 20 & 33.33 \\
\hline Staffs commitment \& cooperation & 34 & 56.66 \\
\hline Internet Access & 37 & 61.66 \\
\hline Librarians' awareness & 52 & 86.66 \\
\hline Promotion/marketing strategies & 28 & 15.55 \\
\hline Time availability & 20 & 33.33 \\
\hline Maintenance & 15 & 25.00 \\
\hline
\end{tabular}

Note: Total sample exceeds the required size since the questions are multiple choices

\subsection{Suggestions}

In light of the above, the followings are recommended for enhanced deployment of Web 2.0 in the Annamalai University library in particular, and the Indian libraries at large.

- Library and Information Sc ience education in India must respond to the changing needs of technological advancement in libraries today. Thus, Web 2.0 technology tools and applications must be a major component in the LIS curriculum.

- Implementing Library 2.0 requires support from the library management as among other it involves financial, infrastructural, and train ing implications. As such, educating and convincing the various parties on how Web 2.0 applications can enhance library services is crucial.

- Some LIS professionals are still doubtful on the application of social networking and IM tools. This could indicate their concerns on the possible impacts of allowing users to have collaborative network and instant communications with the librarians by using such tools. Thus, librarians need to be exposed and educate on how to reposition themselves in this age of Library 2.0 environment. The resistance could be due to their anxiety that these tools will empower users in ways that will change how libraries used to operate and what are to be expected from librarians.

- Future research could look at the possible effects of demographic factors such as age, gender, and years in service, on librarians' perceptions and applications of Web 2.0 tools.

\section{Conclusions}

Web 2.0 and Library 2.0 is yet another wave of rapid development driven by user-centred change that revolutionise and evolves libraries to deliver a new range of functions and services to meet the varying and new demands of its web savvy users. Library 2.0 encourages constant and purposeful change, engages users in the creation of physical and virtual products and services that are being constantly evaluated through feedback, contribution and conversations. Many libraries around the whole have embraced these changes quickly and we now witness a proliferation of new services and functionalities that are unheard of three years ago. Nonetheless, library schools in general, have not kept pace with these changes - they have been slow to react and update their curriculum. There is a need for library schools to act promptly to ensure the gap is closed quickly so that their graduates remain relevant to industry. A number of ways to incorporate Web 2.0 and Library 2.0 education is proposed. We should expect to see a quick response by forward looking library schools to review and adjust their programme and integrate this aspect of education in the near future.

Although this study only addressed a small sample of the Annamalai university Library and Information Science professionals, the findings are still useful in gauging their readiness in embracing Library 2.0. W ith majority of the LIS professionals were aware of Web 2.0 tools coupled with having computer expertise, Lib rary 2.0 has made its way into the Indian libraries. The findings also indicated the trend where the librarians are mainly active users of the Web 2.0 tools. Their willingness to attend trainings shows huge potential of encouraging them to be contributors as well. On the overall, the study found that LIS professionals of Annamalai University hold positive perceptions on Web 2.0 applications. The findings also indicated that most of the LIS professionals had positively accepted and bought the idea of Web 2.0 applications in the library. However, a small number of them were not favorable of some tools such as those for social networking and instant messaging (IM). It could indicate their fear that social networking tools and IM would have some negative effects particularly in delivering lib rary services.

The librarians indicated the importance of attending workshops on Library 2.0. This is another positive indication of their openness in venturing into a more open, flexible, and interactive communications with library customers.

\section{REFERENCES}

[1] O'Reilly, T. (2005). Web 2.0: Compact definition. Accessed April 13 2011, from http://radar.oreilly.com/archives/2005/1 0/web-20-compact-definition.html.

[2] Crawford, W. (2006) Library 2.0 and 'Library 2.0' Cites \& Insights, 6(2), Accessed April 132011 from http://citesandin sights.info/civ6i2.pdf. 
[3] Casey, M. (2006). Library Crunch: Bringing you a Library 2.0 perspective. Accessed April 13 2011, from http://www.librar ycrunch.com/.

[4] Casey, M. (2007). "Looking toward Catalog 2.0" in Library 2.0 and beyond: Innovative technologies and tomorrow's user. London, Libraries Unlimited.

[5] Foo, S., Ng, H., \& Soh, A. (2008). Going virtual for enhance experience: A case study of National Library of Singapore, Proc. VALA 2008 14th Biennial Conference, Melbourne, Australia, February 5-7, Accessed April 22 2011, from http://www.valaconf.org.au/vala2008/papers2008/151_Foo Keynote_Final.pdf.

[6] Macaskill, W. and Owen, D (2006) , "Web2.0 to go", Proceedings LIANZ Conference 2006, Wellington

[7] Huffman,K.(2006), "Web2.0:beyond the concept practical ways to implement RSS, podcasts and wikis," Education Libraries ,Vol29(1),pp 12-19

[8] Miller ,P.(2005) "Web2.0:Building the new Library", Ariadne, No.45, Available at www.ariadne..ac.uk/issue45/mil ler/intr.html

[9] Notess,G.R. (2006) , “ The terrible twos:web2.0,library2.0 andmore",Online, Vol30(3),pp40-42
[10] Franklin, T and Van Harmelen,M(2007), "Web2.0 for content for Learning and Teaching in Higher Education,JISC,Bristol", Available at: www.jisc.ac.uk/media/documents/programmes/ digital repositories/web2-content-learning-and-teaching.pdf

[11] Clyde,L.A.(2004),'Library Web logs", Library Management, Vol25(4-5),pp 183-90

[12] Virkus,Sirje (2008), "Use of web 2.0 technologies in LIS education :experiences at Tallinn University,Estonia,Program Vol42(3),pp262-274

[13] Cohen,Sarah Faye (2008),'Taking 2.0 to the Faculty: Why, Who ,and How", College and Research Libraries News, Vol69(8),pp472-475

[14] Chu, Melanie and Meulemans, Yvonne Nalani (2008), "The Problems and Potential of MySpace and Facebook usage in academic libraries", Internet Reference Services Quarterly, Vol13(1)pp:69-85

[15] Kajewski, MaryAnn (2007), “emerging technologies changing our service delivery models", The Electronic Library, vol 25(4), pp420-429

[16] Bradley.(2007) How to use Web2.0in your Library,Facet,Lo ndon. 